\title{
Response of Soil Properties and Microbial Communities to Agriculture: Implications for Primary Productivity and Soil Health Indicators
}

\author{
Pankaj Trivedi ${ }^{1 *}$, Manuel Delgado-Baquerizo ${ }^{1 t}$, lan C. Anderson ${ }^{1}$ and Brajesh K. Singh ${ }^{1,2}$ \\ ${ }^{1}$ Hawkesbury Institute for the Environment, Western Sydney University, Penrith South, NSW, Australia, ${ }^{2}$ Global Centre for \\ Land Based Innovation, Western Sydney University, Penrith South, NSW, Australia
}

OPEN ACCESS

Edited by:

Karl Ritz,

University of Nottingham, UK

Reviewed by:

Jayanta Kumar Patra,

Yeungnam University, South Korea

Rajan Ghimire

New Mexico State University, USA

*Correspondence:

Pankaj Trived

p.trivedi@westernsydney.edu.au

tThese authors have contributed equally to this work.

Specialty section:

This article was submitted to Agroecology and Land Use Systems,

a section of the journa

Frontiers in Plant Science

Received: 12 September 2015

Accepted: 22 June 2016

Published: 12 July 2016

Citation:

Trivedi P, Delgado-Baquerizo M, Anderson IC and Singh BK (2016)

Response of Soil Properties

and Microbial Communities

to Agriculture: Implications for Primary

Productivity and Soil Health

Indicators. Front. Plant Sci. 7:990.

doi: 10.3389/fpls.2016.00990
Agricultural intensification is placing tremendous pressure on the soil's capacity to maintain its functions leading to large-scale ecosystem degradation and loss of productivity in the long term. Therefore, there is an urgent need to find early indicators of soil health degradation in response to agricultural management. In recent years, major advances in soil meta-genomic and spatial studies on microbial communities and community-level molecular characteristics can now be exploited as 'biomarker' indicators of ecosystem processes for monitoring and managing sustainable soil health under global change. However, a continental scale, cross biome approach assessing soil microbial communities and their functional potential to identify the unifying principles governing the susceptibility of soil biodiversity to land conversion is lacking. We conducted a meta-analysis from a dataset generated from 102 peerreviewed publications as well as unpublished data to explore how properties directly linked to soil nutritional health (total $\mathrm{C}$ and $\mathrm{N}$; $\mathrm{C}: \mathrm{N}$ ratio), primary productivity (NPP) and microbial diversity and composition (relative abundance of major bacterial phyla determined by next generation sequencing techniques) are affected in response to agricultural management across the main biomes of Earth (arid, continental, temperate and tropical). In our analysis, we found strong statistical trends in the relative abundance of several bacterial phyla in agricultural (e.g., Actinobacteria and Chloroflexi) and natural (Acidobacteria, Proteobacteria, and Cyanobacteria) systems across all regions and these trends correlated well with many soil properties. However, main effects of agriculture on soil properties and productivity were biome-dependent. Our metaanalysis provides evidence on the predictable nature of the microbial community responses to vegetation type. This knowledge can be exploited in future for developing a new set of indicators for primary productivity and soil health.

Keywords: soil health, indicators, agriculture intensification, soil bacteria 


\section{INTRODUCTION}

Soil health is the capacity of a soil to function, within natural or managed ecosystem boundaries, to sustain plant productivity, maintain water and air quality, support human well-being, and provide habitats for biodiversity (Doran and Zeiss, 2000; Doran, 2002; Gugino et al., 2009). Human impacts on soil health largely emerge from the need to meet the food, fiber, and fuel demands of an ever increasing population. In the last few decades significant efforts have been made to increase agricultural productivity through increased fertilization and pesticide application, improved irrigation, soil management regimes and crops, and massive land conversions (Tilman et al., 2002). There is increasing concern, however, that agricultural intensification is placing tremendous pressure on the soil's capacity to maintain its other functions leading to largescale ecosystem degradation and loss of productivity in the long term (Tilman et al., 2001; Foley et al., 2005; Vitousek et al., 2009). For example, conversion of natural ecosystems to agricultural lands have incurred substantial environmental costs, including desertification, increased emissions of greenhouse gasses, decreased organic matter in soils, loss of biodiversity, and alterations to biogeochemical and hydrological cycles (Balmford et al., 2005). Modern agriculture thus faces great challenges not only in terms of ensuring global food security by increasing yields but also mitigating the environmental costs particularly in the context of a changing environment and growing competition for land, water, and energy (Chen et al., 2014). Therefore, there is an urgent need to find early indicators of soil health degradation in response to agricultural management (Grime, 1997; Cardoso et al., 2013).

Different terrestrial biomes may respond differentially to agricultural over-exploitation. For instance, arid lands, which occupy $40 \%$ of the globe and sustain $38 \%$ of the human population (Millennium Ecosystem Assessment [MEA], 2005), are very low productivity systems and contain low levels of nutrients (Reynolds et al., 2007; Feng and Fu, 2013). These ecosystems are highly vulnerable to global environmental changes and desertification (Reynolds et al., 2007; Dai, 2013) and may further suffer high reductions in nutrient availability in response to agricultural over-exploitation (Delgado-Baquerizo et al., 2013). On the other hand, highly productive agrosystems such as those from tropical regions may be highly resistance/resilience to agriculture uses, in part due to their rapid organic matter turnover and moisture/water availability (Schlesinger and Bernhardt, 2013). Limited effort has been made to understand the global trends that characterize microbial community composition in natural and agricultural systems (Crowther et al., 2014) which hinder our ability to anticipate the consequences of conversion in the different biomes on Earth.

Evaluation of soil health requires indicators of chemical, physical and biological (including microbial) components contribute to maintaining soil health. Cultivation is known to generally reduce the amount of soil organic matter thus reducing nutrient availability (Schlesinger and Bernhardt, 2013). Similarly, changes in land use are altering both microbial community structure and diversity in terrestrial ecosystems
(Rodrigues et al., 2013). Since soil bacterial communities drive many different ecosystem functions (e.g., Delgado-Baquerizo et al., 2016b), and their abundance, richness, and composition are sensitive to the changes in the land use and management (Gans et al., 2005; Wall et al., 2010; Singh et al., 2014), they have been considered as early indicators of change in the quality of soil ecosystems (Kennedy and Stubbs, 2006). In some instances, changes in microbial populations or activity can precede detectable changes in soil physical and chemical properties, thereby providing an early sign of soil improvement or an early warning of soil degradation (Pankhurst et al., 1997; Nielsen et al., 2002). At local scale fluctuations in microbial diversity and community composition are correlated with reductions in soil $\mathrm{C}$ and nitrogen $(\mathrm{N})$ (Acosta-Martinez et al., 2008, 2010; Jangid et al., 2008; Trivedi et al., 2015). On global scale, however, land use change to agriculture systems on the soil $\mathrm{C}$ and $\mathrm{N}$ contents are more idiosyncratic (Johnson and Curtis, 2001), and negligible effect of conversion has been reported on microbial biomass from several biomes (Holden and Treseder, 2013). Since microorganisms are involved in many soil processes, they may also give an integrated measure of soil health, an aspect that cannot be obtained with physical/chemical measures alone (Nielsen et al., 2002; Kibblewhite et al., 2008; Mueller et al., 2010; Sharma et al., 2011). In recent years, major advances in soil meta-genomic and spatial studies on microbial communities and community-level molecular characteristics can now be exploited as 'biomarker' indicators of ecosystem processes for monitoring and managing sustainable soil health under global change. However, a continental scale, cross biome approach assessing soil microbial communities and their functional potential to identify the unifying principles governing the susceptibility of soil biodiversity to land conversion is lacking.

In the face of current anthropogenic pressure on soil ecosystems, for instance owing to agricultural intensification and climate change, there is a need to better understand the effects of these factors in order to predict and mitigate the impacts of such changes (Kuramae et al., 2012). However, reliable predictions of the potential consequences of perturbations are hampered by the lack of global level baseline knowledge on soil properties and soil microorganisms. Herein we conducted a meta-analysis to explore how soil properties $(\mathrm{pH}$, total $\mathrm{C}$ and $\mathrm{N}$; $\mathrm{C}: \mathrm{N}$ ratio), primary productivity (NPP) and microbial diversity and composition (relative abundance of major bacterial phyla) are affected in response to agricultural management across the main biomes of Earth (arid, continental, temperate and tropical). The aim of the meta-analysis was to identify the impact of agriculture practices on soil nutritional health and microbial communities. We also aimed to examine if the response of microbial community to agriculture is consistent across all the biomes. We collected data from 102 peerreviewed publications as well as unpublished data to create a global dataset of soil bacterial diversity and composition evaluated with next generation sequencing techniques (mostly 454 Pyrosequencing). Our meta-analysis revealed foreseeable nature of the microbial community responses to vegetation types suggesting that the microbial indicators can be developed 


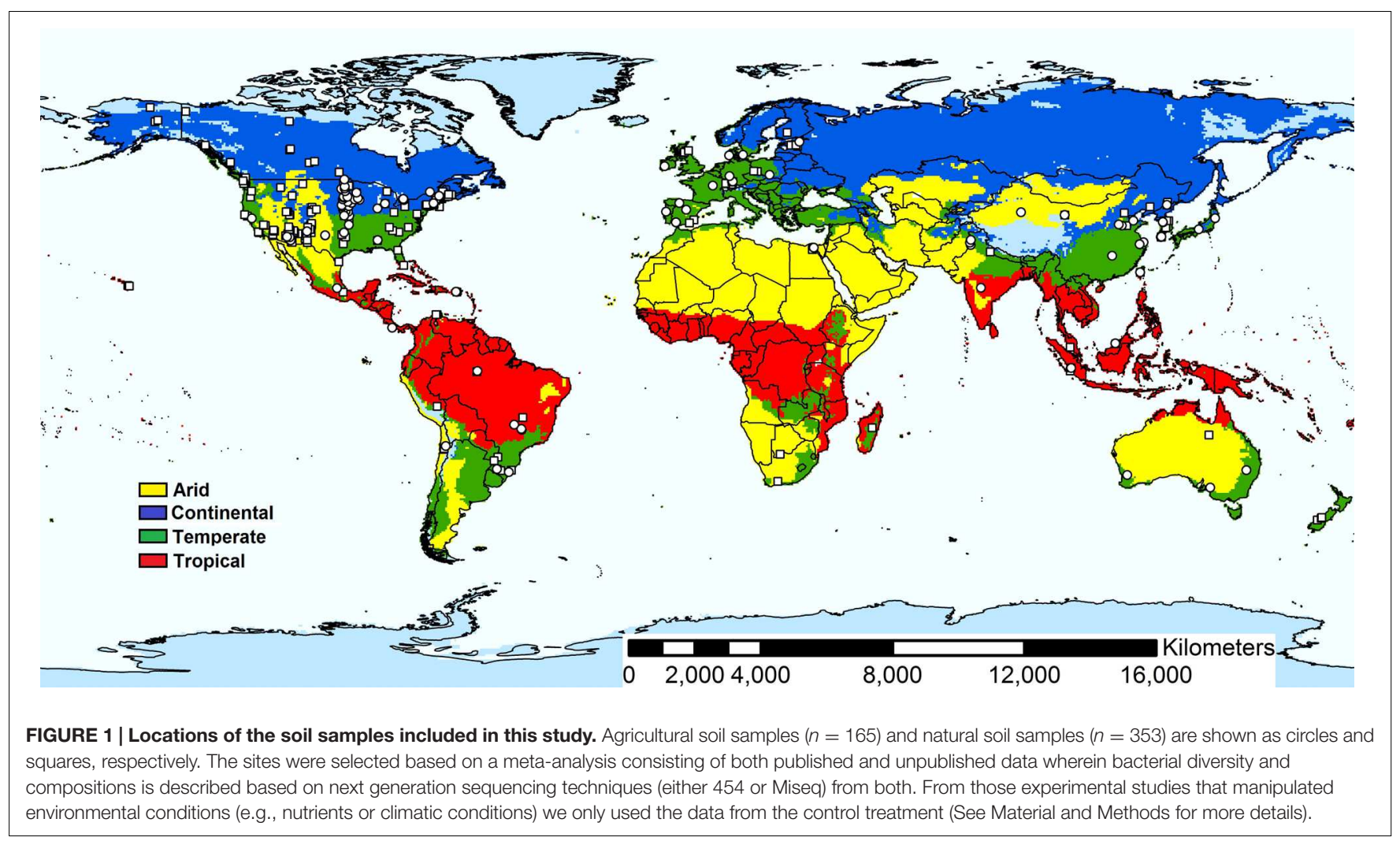

as tools for prediction for primary productivity and soil health.

\section{MATERIALS AND METHODS}

\section{Data Collection}

We collected data on soil bacterial diversity based on next generation sequencing techniques (either 454 or Miseq) from both published and unpublished data. We first conducted a search using SCOPUS ${ }^{1}$ (on September 2014). The following keyword combinations were used: (1) "bacterial community" AND "soil" AND "Pyrosequencing"; and (2) "bacterial community" AND "soil" AND "Illumina." We found $~ 300$ references. Within these references, studies were chosen for inclusion in our analyses only if they met the following criteria: (1) were carried out in the field in terrestrial ecosystems, (2) contained the spatial location where they were carried out (latitude and longitude), as well as data on soil total $\mathrm{C}$ and $\mathrm{pH}$; (3) provided information on Shannon bacterial diversity at $97 \%$ of similarity; (4) included data on the relative abundance of soil bacterial phyla, (5) used next generation sequencing techniques (either 454 or Miseq) and (6) were located in arid, continental, temperate or tropical ecosystems (Koppen classification; Kottek et al., 2006). From those experimental studies that manipulated environmental conditions (e.g., nutrients or climatic conditions) we only used the data from the

${ }^{1}$ http://www.scopus.com/ control treatment. The dataset included geographical locations covering all continents and biomes where agriculture is in practice (Figure 1; Data Sheet S1).

Technical information related to this study (e.g., primer sets, sequencing technology) and validation of the impact of various approaches to generate data on the conclusions is largely discussed in Delgado-Baquerizo et al. (2016a).

\section{Microbial Related Parameters}

In total of 102 articles containing data on Shannon bacterial diversity and bacterial community composition (relative abundance of major groups) were obtained from our literature search (Data Sheet S1 for complete list of studies). We completed this database with data from the National Ecological Observatory Network (NEON; 24 soil samples) in the United States of America ${ }^{2}$, Canadian MetaMicroBiome Library $^{3}$ (11 soil samples) and with unpublished data from sites in Australia (12 soil samples) and Scotland (6 soil samples) (data available from authors). From our meta-analysis we obtained a total of 518 independent soil samples (353 and 165 soil samples belong to natural and agricultural systems, respectively). Bacterial Shannon diversity and composition was available for 61 and $100 \%$ of these sites, respectively.

For all the samples available, we gathered data on the relative abundance of the following major bacteria phyla: Proteobacteria,

\footnotetext{
${ }^{2}$ http://www.neoninc.org/
}

${ }^{3}$ www.cm2bl.org 


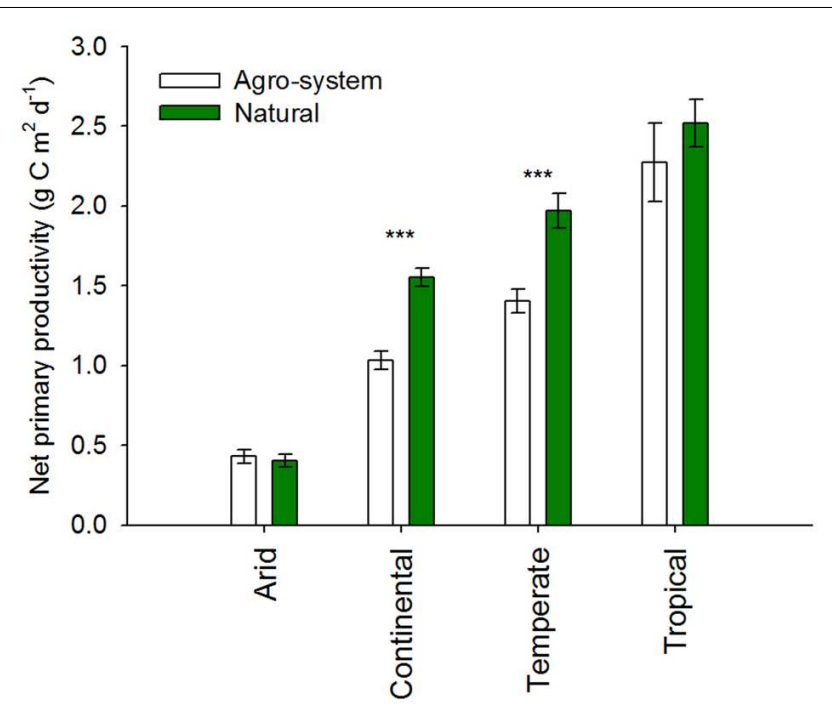

FIGURE 2 | Net primary productivity (measured as $\mathrm{g} \mathrm{C} \mathrm{m}^{2} \mathrm{~d}^{-1}$ ) of agricultural vs. natural systems in arid ( $n=26$ and 70$)$, continental ( $n=43$ and 119), temperate $(n=82$ and 128) and tropical $(n=14$ and 36) regions. Data for primary productivity $\left(\mathrm{g} \mathrm{C} \mathrm{m}^{-2} \mathrm{~d}^{-1}\right)$ was calculated from MODIS satellite imagery data as a monthly average from the 2004-2013 period using information with a $0.1^{\circ}$ spatial resolution (http://neo.sci.gsfc.nasa.gov/). The main climate classes are based on global maps available for the most frequently used Köppen climate classification map (Kottek et al., 2006). ${ }^{* * *} P<0.0001$.

Acidobacteria, Actinobacteria, Verrucomicrobia, Bacteroidetes, Chloroflexi, Cyanobacteria, Firmicutes, Gemmatimonadete, Plantomycetes.

\section{Soil Properties and Net Primary Productivity (NPP)}

We collected information on the following soil properties: soil total $\mathrm{C}$, total $\mathrm{N}, \mathrm{C}: \mathrm{N}$ ratio and $\mathrm{pH}$ from the studies selected for meta-analysis. Most of the studies in our metaanalysis used elemental $\mathrm{CNH}$ analyzer for the estimation of soil C. This method analyzes both inorganic and organic carbon hence can overestimate the amount of SOC in the samples. Data for NPP $\left(\mathrm{g} \mathrm{C} \mathrm{m} \mathrm{m}^{-2} \mathrm{~d}^{-1}\right)$ was calculated from MODIS satellite imagery data as a monthly average from the 2004 to 2013 period using information with a $0.1^{\circ}$ spatial resolution $^{4}$.

\section{Ecosystem Classification}

We determined the main climate classes in each of the study sites based on global maps available for the most frequently used Köppen climate classification map (Kottek et al., 2006): A (tropical), B (arid), C (temperate), and D (continental). We completed climate gaps in our dataset using local and regional database. These analyses were done with ESRI ArcGIS Desktop 10.

${ }^{4}$ http://neo.sci.gsfc.nasa.gov/

\section{Statistical Analyses}

We used two-way ANOVAs to evaluate changes in NPP, soil properties and microbial community features (main bacterial phyla and Shannon diversity) among different biomes (arid, temperate, continental and tropical) and land use type (agricultural vs. natural). Biomes and land use type were included as fixed factors in these analyses. These statistical analyses were carried out using IBM SPSS 15.0 (SPSS Inc, Chicago, IL, USA). We also used Spearman correlation analyses to evaluate the relationship between microbial community features (main bacterial phyla and Shannon diversity) with soil properties and NPP.

\section{RESULTS}

\section{NPP and Soil Properties of Agricultural vs. Natural Soils in Different Regions}

Net primary productivity (measured as $\mathrm{g} C \mathrm{~m}^{2} \mathrm{~d}^{-1}$ ) was significantly higher in natural as compared to agro-systems from continental and temperate regions $(P<0.0001)$ (Figure 2). However, our meta-analysis did not reveal a significant difference between agricultural and natural ecosystems for arid and tropical regions (Figure 2). $\mathrm{pH}$ of agriculture soils from continental, temperate, and tropical regions were higher than natural soils (Figure 3A). The data revealed an approximate increase of 1.5, 1.0 and 0.5 units in soil $\mathrm{pH}$ from agriculture soils as compared to natural soils in continental $(P<0.0001)$, temperate $(P<0.0001)$ and tropical $(P<0.01)$ regions, respectively. There was no difference in the $\mathrm{pH}$ values associated with agricultural vs. natural soils in arid regions.

Soil \% C in natural soils from temperate regions was approximately $8.0 \%$ and this was significantly higher $(P<0.01)$ than the agricultural soils $(\sim 5.5 \%$, Figure $3 B)$. The data revealed no significant difference in the $\%$ of total $\mathrm{C}$ in agricultural vs. natural soils from continental and tropical regions. In arid regions, our meta-analysis revealed significantly higher $(P<0.01) \%$ of total $\mathrm{C}$ in agricultural as compared with natural soils. In arid regions the \% of total $\mathrm{C}$ was approximately 2.5 and $1.7 \%$ for agricultural and natural soils, respectively.

Our analysis revealed variability in the soil $\mathrm{N}$ content when comparing agricultural vs. natural soils from different regions. In arid regions, the total $\mathrm{N} \%$ in agricultural soils was approximately $0.22 \%$ which was significantly higher $(P<0.001)$ than natural soils $(\sim 0.15 \%$, Figure $3 \mathrm{C})$. We observed no significant trends in $\%$ of soil $\mathrm{N}$ in agricultural vs. natural soils in the other three regions. However, agricultural soils from continental regions had a higher $\mathrm{N}$ content compared to natural soils while the opposite trend was observed in temperate regions. The $\% \mathrm{~N}$ of agricultural and natural soils was similar in tropical regions.

As an average, arid and temperate regions showed the lowest and highest $\mathrm{C}: \mathrm{N}$ ratio in this study, respectively (Figure 3D). The $\mathrm{C}: \mathrm{N}$ ratio of agricultural soils from arid and tropical regions was higher $(p<0.01)$ when compared to natural soils from similar regions. In contrast, the $\mathrm{C}: \mathrm{N}$ ratio of natural soils was significantly higher $(P<0.0001)$ than agricultural soils in temperate regions. 
A

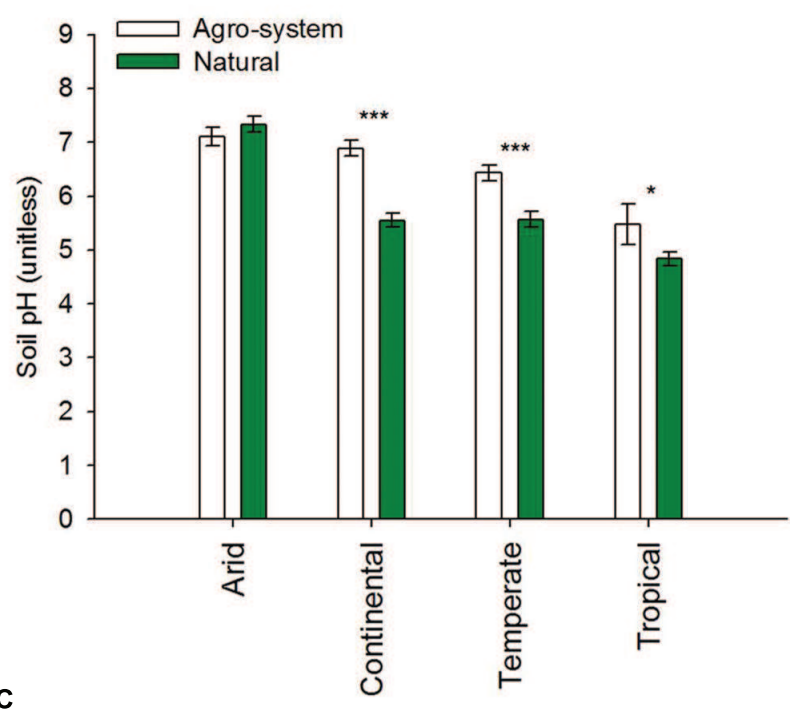

B
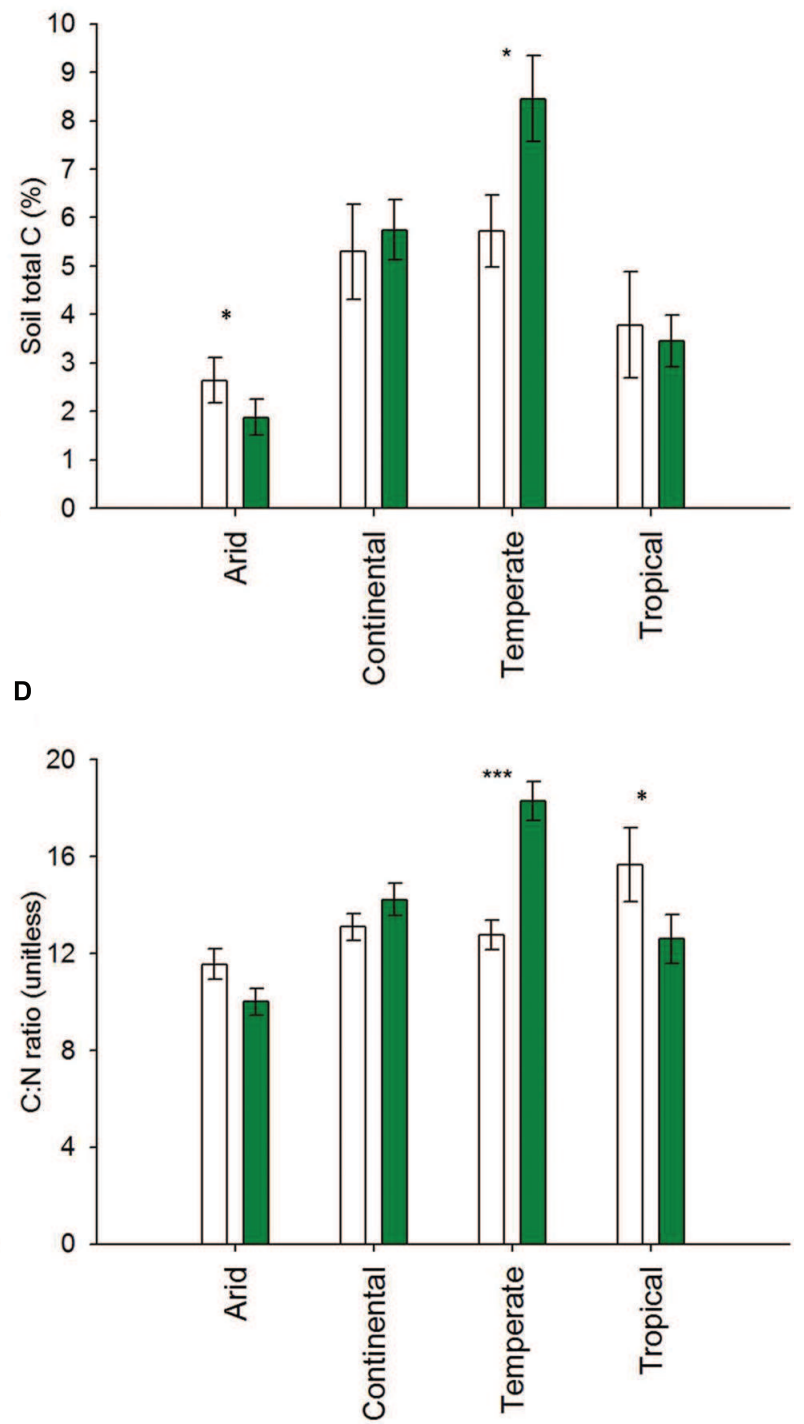

FIGURE 3 | Soil chemical properties [(A) Soil pH; (B) Soil total C (\%); (C) Soil total N (\%); and (D) C/N ratio] of agricultural vs. natural systems in arid ( $n=26$ and 70), continental ( $n=\mathbf{4 3}$ and 119), temperate $(n=82$ and 128) and tropical $(n=14$ and 36$)$ regions. The sites were selected based on a meta-analysis consisting of both published and unpublished data wherein bacterial diversity and compositions is described based on next generation sequencing techniques (either 454 or Miseq; see Material and Methods for more details). The main climate classes are based on global maps available for the most frequently used Köppen climate classification map (Kottek et al., 2006). ${ }^{*} P<0.01$; ${ }^{* *} P<0.001 ;{ }^{* *} P<0.0001$.

In continental regions there was no significant difference in the $\mathrm{C}: \mathrm{N}$ ratio from agricultural and natural soils.

\section{Microbial Data}

Microbial Diversity in Agricultural vs. Natural Systems in Different Regions

We selected the Shannon diversity index as our metric of alpha diversity because it is highly recommended and commonly used when analyzing microbial diversity (He et al., 2013), and has been shown to reduce the bias in relation to other diversity metrics, such as the number of OTUs, when comparing data from multiple sources (He et al., 2013). Our analysis revealed significantly higher microbial diversity in agricultural systems as compared to natural systems in arid $(P<0.01)$ and temperate $(P<0.001)$ regions (Figure 4). Microbial diversity was lower in agricultural systems in continental and tropical regions as compared with natural systems; however, the trends were not statistically significant.

\section{Relative Abundance of Bacterial Phyla in Agricultural vs. Natural Soils in Different Regions}

The relative abundance of major bacterial phyla in agricultural and natural soils from different regions is presented in Figure 5. The relative abundance of Acidobacteria was significantly 


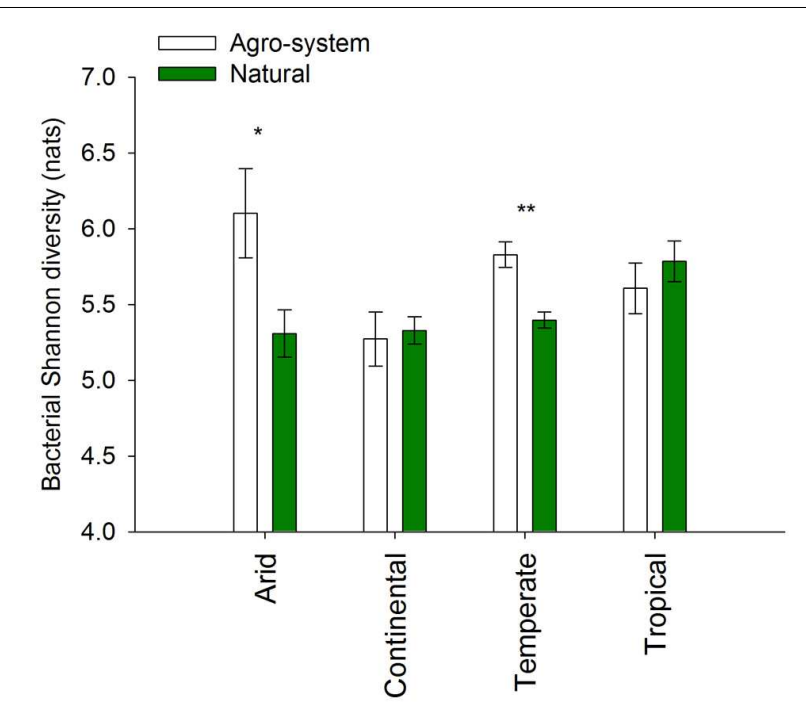

FIGURE 4 | Bacterial Shannon diversity of agricultural vs. natural systems in arid ( $n=26$ and 70$)$, continental ( $n=43$ and 119), temperate $(n=82$ and 128$)$ and tropical $(n=14$ and 36$)$ regions. The sites were selected based on a meta-analysis consisting of both published and unpublished data wherein bacterial diversity and compositions is described based on next generation sequencing techniques (either 454 or Miseq; see Material and Methods for more details). The main climate classes are based on global maps available for the most frequently used Köppen climate classification map (Kottek et al., 2006). ${ }^{*} P<0.01$; ${ }^{* *} P<0.001$.

greater in natural soils as compared to agricultural soils from arid $(P<0.001)$, continental $(P<0.0001)$, and temperate $(P<0.0001)$ regions. In arid regions, the relative abundance of Acidobacteria was nearly three times greater in natural soils as compared to agricultural soils. Similar to other regions, our metaanalysis showed higher relative abundance of Acidobacteria in natural vs. agricultural soils in tropical regions, however, this was not statistically significant. Our meta-analysis revealed higher relative abundance of phylum Proteobacteria in natural soils as compared to agriculture soils from all the studied regions. This trend was significant in soil from continental $(P<0.01)$, temperate $(P<0.0001)$, and tropical regions $(P<0.01)$. Our analysis further revealed significantly higher relative abundance of Cyanobacteria in natural soils vs. agricultural soils from arid $(P<0.0001)$, continental $(P<0.01)$, and temperate $(P<0.01)$ regions. Interestingly in arid regions the relative abundance of this group was approximately 6 fold higher in natural as compared to agricultural soils.

In contrast we observed higher relative abundance of Chloroflexi in agricultural soils as compared to natural soils across all regions. The relative abundance of this phylum was 2 and 6 fold higher in agriculture soils as compared to natural soils from arid $(P<0.001)$ and temperate regions $(P<0.0001)$, respectively.

The relative abundance of phylum Actinobacteria was significantly higher in natural vs. agricultural soils from continental regions while an opposite trend was observed in soils from tropical regions. Our analysis did not showed significant differences in the relative abundance of this phylum when agriculture and natural soils were compared from arid and temperate regions. Firmicutes showed significant differences among agricultural and natural soils only in arid regions $(P<0.0001)$ where the relative abundance was approximately 5 fold higher in agricultural soils. The members of phylum Verrucomicrobia were significantly more abundant in agricultural soils as compared to natural soils from continental $(P<0.0001)$ and tropical $(P<0.01)$ regions while the relative abundance of Planctomycetes was significantly higher in natural soils compared to agricultural soils $(P<0.01)$ from continental regions (Figure 5).

\section{Correlations between the NPP and Soil Properties with the Relative Abundance of Different Bacterial Phyla Across Different Regions}

The correlations between the NPP and soil properties with the microbial data are presented in Supplementary Table S1. Bacterial diversity of the arid regions was significantly correlated with NPP $(\rho=0.520 ; P<0.001)$. However, in our analysis we did not observe the same correlation in other regions. In arid regions, the relative abundance of phylum Chloroflexi $(\rho=-0.213 ; P=0.037)$ and Proteobacteria $(\rho=0.283$; $P<0.005)$ was correlated with NPP. The relative abundance of phylum Cyanobacteria was negatively correlated with total soil C $(\rho=0.206 ; P<0.044)$ and the $\mathrm{C}: \mathrm{N}$ ratio of arid regions.

Our analysis showed an increase in the number of correlations between the relative abundance of various bacterial phyla, NPP and soil properties in continental and temperate regions. For example, in continental regions significant correlations were observed between the NPP and the relative abundance of Acidobacteria $(\rho=0.347 ; P<0.001)$, Actinobacteria $(\rho=-0.190$; $P=0.016)$, Chloroflexi $(\rho=-0.276 ; P<0.001)$, and Firmicutes $(\rho=0.336 ; P<0.001)$. In temperate regions, NPP and soils properties were correlated with the relative abundance of many different bacterial phyla. For example, in temperate regions NPP was significantly correlated with the relative abundance of all bacterial phyla except for Plantomycetes. Soil C was correlated with the relative abundance of Acidobacteria, Firmicutes, Verrucomicrobia, and Proteobacteria. In fact, in temperate regions the relative abundance of phylum Acidobacteria, Firmicutes, and Proteobacteria was significantly correlated with NPP and all soil properties analyzed in this meta-analysis. In tropical regions, NPP was correlated with the abundance of Chloroflexi $(\rho=0.346 ; P=0.014)$ and Verrucomicrobia ( $\rho=0.294 ; P=0.038)$. With respect to this region, the data showed no significant correlation between total soil $\mathrm{C}$ and the relative abundance of different bacterial phyla.

\section{DISCUSSION}

\section{NPP Differed between Agricultural and Natural Systems Only in Continental and Temperate Biomes}

Terrestrial NPP represents the total annual growth of land vegetation and is the basic resource for food, fiber, and energy (Vitousek et al., 1986; Running, 2012; Krausmann et al., 2013). In 

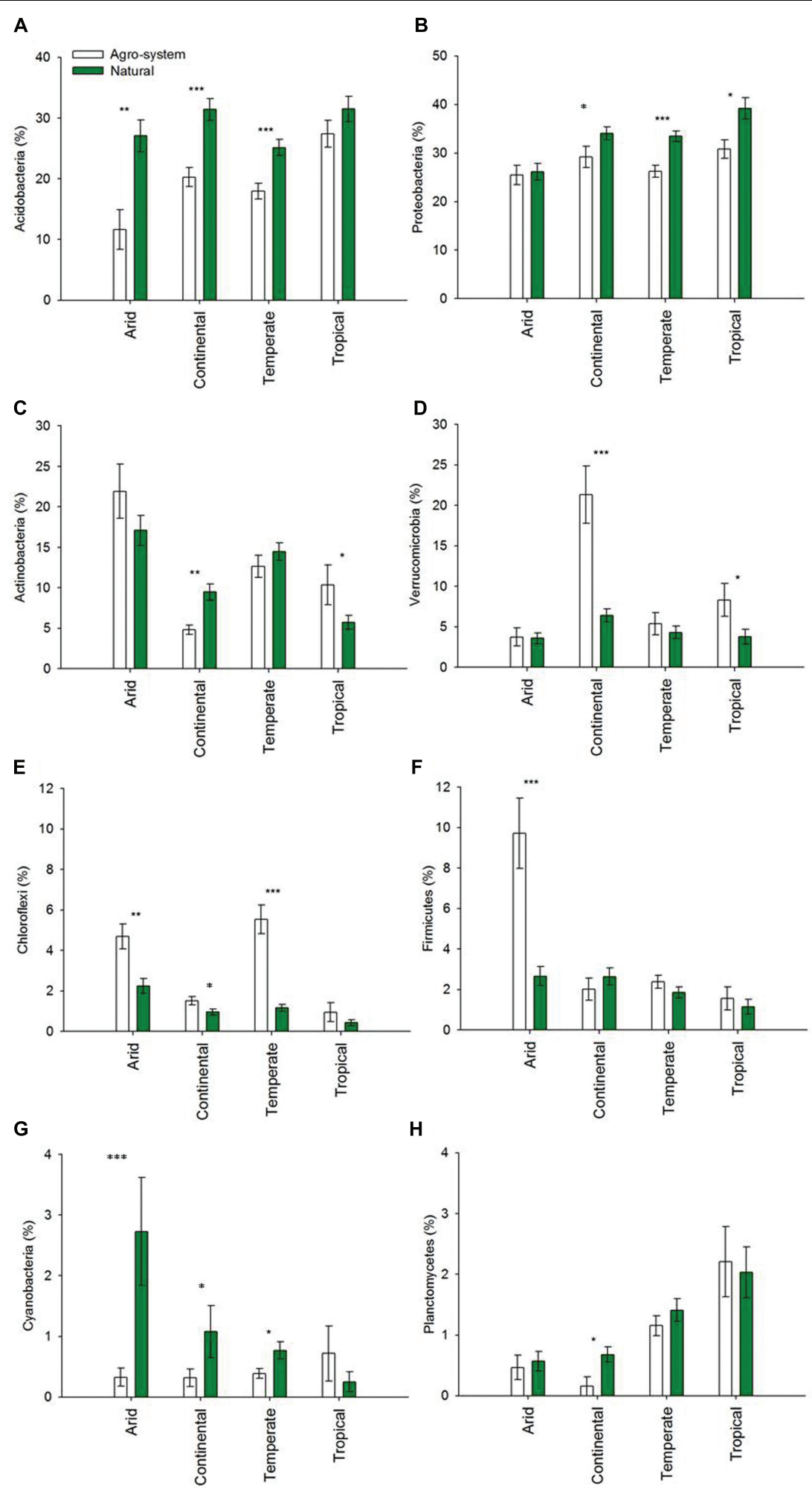

FIGURE 5 | Relative abundance of major bacterial phylum [(A) Acidobacteria; (B) Proteobacteria; (C) Actinobacteria; (D) Verrucomicrobia; (E) Chloroflexi; (F) Firmicutes; (G) Cyanobacteria; and (H) Planctomycetes] in agricultural vs. natural systems in different regions. The sites were selected based on a meta-analysis consisting of both published and unpublished data wherein bacterial diversity and compositions is described based on next generation sequencing techniques (either 454 or Miseq; see Material and Methods for more details). The main climate classes are based on global maps available for the most frequently used Köppen climate classification map (Kottek et al., 2006). ${ }^{*} P<0.01 ;{ }^{* *} P<0.001 ;{ }^{* * *} P<0.0001$. 
addition, terrestrial NPP is also a major component of the global $\mathrm{C}$ cycle, and a critical precursor to net $\mathrm{C}$ storage. Changes in NPP due to agricultural conversion could result in either enhancing or mitigating increments in atmospheric $\mathrm{CO}_{2}$ concentrations and climate warming (Fargione et al., 2008; Searchinger et al., 2008). Latitudinal control of insolation (solar radiation that reaches earth surface) on photosynthesis results in a noticeable decrease in NPP from tropical ecosystems to those in the middle or higher latitudes (Figure 2). It is generally assumed that agricultural ecosystems are significantly less productive (e.g., by harvest-induced reductions in growing season length) than natural systems in the same environment (Smith et al., 2014). On the contrary it can also been argued that agricultural conversion at a local scale can increase NPP (e.g., by management inputs that reduce biophysical growth limitations) (Long et al., 2006). In our analysis we observed a significant reduction in NPP in agroecosystems as compared to natural ecosystems in continental and temperate environments (Figure 2). In similar environments, Smith et al. (2014) have reported a significant decrease in NPP due to agricultural conversion that was independent of conversion type, management intensity, crop type, or regions. Our analysis revealed a decrease in NPP in agro-ecosystems in tropical regions (Figure 2), however it was not as steep as reported by other workers (Smith et al., 2014). As most of our sites in tropical regions were situated in the industrialized west and Asia, the non-significant decrease in NPP in agricultural sites might be due to the relatively intensive management practices and crop types which could contribute to higher rates of productivity that more closely match those of natural vegetation (Gelfand et al., 2013; Smith et al., 2014). Similarly, in arid regions our analysis showed no differences between NPP of agricultural and natural systems (Figure 2). It seems that in nutrient poor systems, such as arid system climate constrains do not allow an increase in NPP. In arid regions, water availability will be the major constraint on NPP and the plants will be more sensitive to precipitation variation than soil management (Zhu and Southworth, 2013).

\section{Trends Obtained from Properties Linked to Soil Nutritional Health Were Not Consistent in Agriculture vs. Natural Systems among All the Climatic Regions}

Agriculture practices generally results in a decline in soil nutrients. However, nutrients inputs, from both natural and synthetic sources can improve plant growth that increases organic matter returns leading to improvement in soil quality (Smith et al., 2015). Changes in soil properties can vary markedly with type of land cover, climate, and method, extent of vegetation removal (e.g., land clearing, fires, mechanical harvest), and management post harvests. Here we discuss trends obtained from our meta-analysis on the soil chemical properties of agricultural vs. natural systems in different climatic regions.

\section{Soil Carbon}

As the dominant land-use change during the past century, conversion of natural systems for agricultural production has greatly altered soil $\mathrm{C}$ dynamics at ecosystem, regional, and global scales (Foley et al., 2005; Bala et al., 2007; Don et al., 2011; Yonekura et al., 2012; Zhang et al., 2015). The depletion of soil total $\mathrm{C}$ due to the intensification of agriculture and land-use change from natural to croplands is exacerbated through agricultural practices with low return of organic material and other various factors including oxidation/mineralization, leaching and erosion (Post and Kwon, 2000; Wu et al., 2003; Lal, 2004; Zhang et al., 2015). In a meta-analysis, Guo and Gifford (2002) showed that the conversion of native forests and pastures to croplands reduced soil C stocks by 42 and 59\%, respectively. The results varied, however, depending on factors such as annual precipitation, plant species and, the length of study periods. Our analysis indicated that total C \% of agricultural soils were lower as compared to natural soils in temperate regions (Figure 3B). However, no significant difference in total $\mathrm{C} \%$ in agricultural vs. natural systems were observed in other regions.

Previous studies have reported negative, positive, and negligible effects of land conversion on soil C content (Bashkin and Binkley, 1998; Vesterdal et al., 2002; Yang et al., 2011; Zhang et al., 2015). For example, 13\% of the croplands included in a meta-analysis on the impact of tropical land use change on soil organic matter reported similar to higher soil $\mathrm{C}$ stocks in agricultural soils than forests (Don et al., 2011). The different sampling schemes, estimation methods, and the complexity of factors affecting soil $\mathrm{C}$ dynamics are attributed to the inconsistency in various studies (Don et al., 2011; Li et al., 2012). Following the land-use change, litter input from new vegetation will be terminated and replaced by litter from new vegetation, while the soil $\mathrm{C}$ derived from the former litter would be decomposed and mineralized by soil microbes (Zhang et al., 2013). Thus soil C stocks would be controlled not only by the degradation of old $\mathrm{C}$ (soil $\mathrm{C}$ previous to conversion) but also by the addition of new soil $\mathrm{C}$ ( $\mathrm{C}$ derived from new vegetation after land use) (Del Galdo et al., 2003; Mendez-Millan et al., 2014). Our observations, particularly in Continental and Tropical regions, is in contrast to most previous studies (Guo and Gifford, 2002; Don et al., 2011) that have reported significant lower soil C in agricultural soil as compared to natural soils. This discrepancy may arise due to differences in management practices and disturbance regimes including tillage, residue retention, grazing and the duration of change in land use. Wiesmeier et al. (2015) has reported that soil cultivation may not generally result in the strong decline in soil $\mathrm{C}$ content, as management practices such as tillage probably promote the formation of organo-mineral associations and relocation of soil $\mathrm{C}$ with depth may decrease decomposition. No significant change in soil $\mathrm{C}$ in agricultural soils in arid/tropical regions results from boosted productivity and higher turnover rates adding more $\mathrm{C}$ to the soil due to organic manure/fertilizer application as well as the effect of crop residue, and irrigation regimes (Zhang et al., 2013).

\section{Soil N}

Conversion of natural lands into arable lands is not only characterized by losses of ecosystem C stocks, but also by significant losses of ecosystem $\mathrm{N}$ stocks along hydrological pathways, gaseous volatilization or through erosion (Tiessen 
et al., 1982; McLauchlan, 2006). A meta-analysis using mainly data from tropical sites indicated that the average loss of soil $\mathrm{N}$ after conversion of forests to croplands was 15\% (Murty et al., 2002). Dalal et al. (2013) reported that conversion of native vegetation to perennial pasture and cropland in Australia resulted in $\mathrm{N}$ losses of more than 20 and 38\%, respectively. Our analysis did not revealed significant differences in soil $\mathrm{N} \%$ between agricultural and natural soils from continental, temperate, and tropical regions. We argue that the extensive use of chemical $\mathrm{N}$ fertilizer in agricultural soils will compensate for $\mathrm{N}$ losses through natural processes thereby maintaining total soil $\mathrm{N}$ concentrations to the levels similar to natural soils. In addition, the introduction of leguminous plants to crop rotations (Tiessen et al., 1982) or the application of organic fertilizers (Griffin et al., 2005), can support an increase in N stocks. Our analysis showed a significant higher total soil $\mathrm{N}$ in agricultural systems from arid regions compared to natural systems. In arid regions SOC and N stocks have been reported to depend strongly on soil types with strong interactions between soil type and land use (Mayes et al., 2014). Increases in the soil $\mathrm{N}$ in arid regions might also be the result of preference to grow leguminous crops which have a lower water requirement (Creswell and Martin, 1998).

\section{Soil pH}

Comparing soils from a similar climate in tropical, continental, and temperate regions, soils from agricultural systems tend to be more alkaline than natural soils. Liming in agricultural soils is also one of the major factors leading to an increase in soil $\mathrm{pH}$ (Armstrong et al., 2015). The greatest (positive) effects with $\mathrm{pH}$ were seen in the acidic soils, however, in arid regions where the $\mathrm{pH}$ tends to be more alkaline, our analysis showed no significant differences between agricultural vs. natural soils suggesting that impact of agricultural practices was soil dependent. Contrary to agricultural systems, natural ecosystems trend to be more acid in general. This difference in acidity can be generated through several mechanisms, including increased production of organic acids or through the generation of carbonic acid from higher rates of autotrophic respiration in natural soils (Richter and Markewitz, 1995). The increased acidity of forests may also be caused by increased uptake of cations by trees and consequent changes in the proportions of cations adsorbed to the soil exchange complex (Jobbagy and Jackson, 2004). Berthrong et al. (2009) have reported that higher acidity in natural soils can also be driven by changes in the proportions of cations such as $\mathrm{Ca}, \mathrm{Mg}, \mathrm{Na}$, and $\mathrm{K}$.

\section{Response of Soil Bacterial Community}

It could be argued that our analyses suffer from biases such as those related to the different primer sets used by the studies included in our database. However, results from our previous study (Delgado-Baquerizo et al., 2016b) clearly demonstrate that primers pairs, sequencing platform, and the method of soil sampling does not significantly alter the microbial diversity and relative abundance of major soil bacterial phyla and that next generation sequencing data can be as useful as other available data to evaluate global patterns in microbial ecology. We argue that the point of variability in the results on the relative abundance of major bacterial phyla using different primerset (Engelbrektson et al., 2010; Cai et al., 2013; Fredriksson et al., 2013) can be critical in local studies as in these cases the variability among primer sets may overlap the spatial variability within a particular plot or the effects of a given treatment on the abundance of these bacteria. However, small changes in relative abundance of different phyla that could be attributed to using different primer sets (Engelbrektson et al., 2010; Cai et al., 2013; Fredriksson et al., 2013) is unlikely to bias results from a global-scale meta-analysis like the one performed in the present study (Delgado-Baquerizo et al., 2016b). These variations are indeed a part of the intrinsic noise one may expect in similar meta-analyses conducted with other soil microbial variables (Fierer et al., 2009; Serna-Chavez et al., 2013).

\section{Microbial Diversity in Agriculture vs. Natural Systems}

Understanding the mechanisms that control the extent to which soil properties and microbial communities change following the conversion of natural to agricultural systems is of paramount importance to comprehend the consequences of land use changes for soil health and agricultural productivity (Sala et al., 2000). Management practices such as tillage and crop rotation; periodic fertilization; and pesticide application generate temporal and spatial changes in soil physical and chemical properties in agricultural systems (Carbonetto et al., 2014). The agricultural systems thus represents rapidly fluctuating environments with highly variable resource gradients and greater bio-physical and chemical heterogeneity as compared to natural systems, thereby providing a wide range of niches for microbial growth. This variability and heterogeneity can result in increased diversity in agricultural systems as compared to stable natural systems. In fact our meta-analysis revealed that microbial diversity increased significantly in agricultural systems of arid and temperate regions (Figure 4). The fact that diversity increased or was not markedly altered (continental and tropical regions) as a consequence of agriculture activities is not unexpected. In fact, microbial communities in natural systems may be limited by nutrient availability and therefore fertilizer addition may allow colonization by new species from the regional pools (Jangid et al., 2008; Upchurch et al., 2008; Jesus et al., 2009; LeeCruz et al., 2013; Crowther et al., 2014; Figuerola et al., 2015). However it has been reported that although local taxonomic and phylogenetic diversity of soil bacteria increases after conversion, communities become more similar across space (Rodrigues et al., 2013; Figuerola et al., 2015). The homogenization of microbial communities in response to human activities is driven by the loss of soil bacteria with restricted ranges (endemics) from the natural systems and results in a net loss of diversity (Rodrigues et al., 2013; Figuerola et al., 2015). As soil microbial diversity drives multiple ecosystem functions related to plant productivity (Delgado-Baquerizo et al., 2016a), we argue that microbial biodiversity loss (through homogenization of microbial community) should be taken into account when assessing the impact of land use change. 


\section{Relative Abundance of Major Bacterial Phyla in Agricultural vs. Natural Systems}

In our analysis, despite the complex nature of soil microbial communities, we found general patterns characterizing microbial community responses to land use change at the continental scale which can provide strong framework for future experiments to generate empirical evidence. Across all regions, the relative abundance of phylum Acidobacteria was significantly greater in natural ecosystems as compared to agricultural systems (Figure 5). In contrast the relative abundance of Verrucomicrobia was higher in agro-ecosystems in continental, temperate and tropical regions. Interestingly both of these groups are classified as "oligotroph" (r-strategists, Fierer et al., 2007; Trivedi et al., 2013) based on lower growth rates and on a preference for growing on relatively recalcitrant forms of C. Although both Acidobacteria and Verrucomicrobia seems to be dominant groups in soil, their ecology remains poorly understood as the members of these group are difficult to culture and study in the laboratory (Bergmann et al., 2011; Fierer et al., 2013). The negative effect of agricultural systems on Acidobacteria may be also related to higher $\mathrm{pH}$ in agro-ecosystems compared to natural ecosystems.

The relative abundance of Proteobacteria was higher in natural soils as compared to agricultural soils in all regions apart from arid regions (Figure 5). Many members of Proteobacteria are classified as plant growth promoting bacteria that facilitates nutrient acquisition and provides protection against diseases (Lugtenberg and Kamilova, 2009). Lower relative abundance of Proteobacteria in agricultural soils can thus have important implications for plant productivity and soil health. Interestingly, we observed that the decrease in proportion of Cyanobacteria was accompanied by an increased proportion of Chloroflexi in agricultural systems of Arid, Continental, and Temperate regions. The metabolic flexibility of Chloroflexi (Strauss and Fuchs, 1993) can provide a competitive advantage against Cyanobacteria for limiting nutrients or physical space when they co-occur in the same environment especially in fluctuating environmental conditions in agricultural soils. Change in the ratio between Cyanobacteria and Chloroflexi has been implicated to be the result of physical disturbances that lead to the destruction of the microscale topography, decreased $\mathrm{N}$ availability and likely altered soil moisture retention and soil surface albedo (Kuske et al., 2012). Therefore, the relationship between these two related phyla in soil environments has to be investigated in details to develop early warning tools for soil degradation.

\section{Microbial Indicators of Soil Fertility and Primary Productivity}

The results of our meta-analysis provide useful information about the global distribution of several groups of numerically abundant bacterial phyla in agricultural vs. natural systems across contrasting climatic regions. It was demonstrated that certain bacterial phyla responded differentially to the conversion of natural to agro-ecosystems and the trend was consistent across all studied regions. For example, the relative abundance of Acidobacteria was higher in natural systems while the abundance of Chloroflexi was higher in agricultural systems. In our analysis, the dataset is derived from the relative abundance of major bacteria groups using next generation sequencing; however, previous studies have shown a significant correlation between the relative abundance and absolute numbers of major bacterial groups using $\mathrm{QPCR}$ (Trivedi et al., 2015). Our findings highlight the potential of molecular tools to identify bacterial groups that may serve as potential indicators to assess the sustainability of agricultural soil management and to monitor trends in soil condition over time.

It can be argued that the selection of indicator species based solely on the frequency of occurrence does not permit conclusions about the process in which they are involved (Figuerola et al., 2012). However, as discussed above the relative abundance of groups showing consistent trends in abundance in natural and agricultural systems across all the regions can be inferred by their trophic life-strategies and related to soil physio-chemical parameters. Therefore, it can be validly postulated that the abundance of these groups reflects true habitat specialization underlying ecological selection based on soil management. The abundance of the suggested bacterial phyla is easily measured since well-established molecular and conventional culturing protocols for quantification are available (Fierer et al., 2012); they are sensitive to soil management actions and are integrative, i.e., provide adequate coverage across a relatively wide range of ecological variables, soil types, climate, crop sequence, etc. Herein we provide a regional scale framework for developing appropriate tests for simple monitoring of proposed candidate biological indicators that can be integrated into a minimum dataset, to facilitate measuring the impact of agriculture on soil health. This will allow the development of base-line values and ranges to incorporate microbial indicators in management decisions. However, significant background work including identifying context of monitoring (aridity vs. productivity), selection parameters for biological indicators (positive or negative) need to be tested and validated before an efficient indicator of primary productivity can be developed for monitoring purpose.

\section{CONCLUSION}

We provide a detailed characterization of how bacterial communities change following the conversion of natural to agricultural systems, and reveal community-scale trends that hold across tropical, temperate, continental, and arid biomes. We propose that measures of microbial abundance may serve as indicators of changing to soil health before actual decline in physico-chemical properties are detected. Although our metaanalysis is derived from comprehensive datasets on the effect of agriculture on soil properties and the relative abundance of microbial taxa, this global dataset does not mirror the current hot spots of land use changes. New efforts are needed to quantify the effect of land use changes in South East Asia and Africa, also taking to account the carbon-rich wetland forests and 
degradation cascades within land-use classes. Nevertheless our meta-analysis provides clear signals on the predictable nature of the microbial community responses to land-use types which can be used to conceptualize future studies on understanding of human decision-making for soil health and biodiversity.

\section{AUTHOR CONTRIBUTIONS}

PT and MD-B designed this study and performed the metaanalysis in consultation with BS. Statistical analyses were done by PT and MD-B in consultation with BS and IA. PT wrote the article, with contributions from all co-authors.

\section{REFERENCES}

Acosta-Martinez, V., Burow, G., Zobeck, T. M., and Allen, V. G. (2010). Soil microbial communities and function in alternative systems to continuous cotton. Soil Sci. Soc. Am. J. 74, 1181-1192. doi: 10.2136/sssaj2008.0065

Acosta-Martinez, V., Dowd, S., Sun, Y., and Allen, V. (2008). Tag-encoded pyrosequencing analysis of bacterial diversity in a single soil type as affected by management and land use. Soil Biol. Biochem. 40, 2762-2770. doi: 10.1016/j.soilbio.2008.07.022

Armstrong, R. D., Eagle, C., and Flood, R. (2015). Improving grain yields on a sodic clay soil in a temperate, medium-rainfall cropping environment. Crop Pasture Sci. 66, 492-505. doi: 10.1071/CP14210

Bala, G., Caldeira, K., Wickett, M., Phillips, T. J., Lobell, D. B., Delire, C., et al. (2007). Combined climate and carbon-cycle effects of large-scale deforestation. Proc. Nat. Acad. Sci. U.S.A. 104, 6550-6555. doi: 10.1073/pnas.0608998104

Balmford, A., Bennun, L., Brink, B. T., Cooper, D., Cote, I. M., Crane, P., et al. (2005). The convention on biological diversity's 2010 target. Science 307, 212-213. doi: 10.1126/science.1106281

Bashkin, M. A., and Binkley, D. (1998). Changes in soil carbon following afforestation in Hawaii. Ecology 79, 828-833. doi: 10.1890/0012-9658(1998)079[0828:CISCFA]2.0.CO;2

Bergmann, G. T., Bates, S. T., Eilers, K. G., Lauber, C. L., Caporaso, J. G., Walters, W. A., et al. (2011). The under-recognized dominance of Verrucomicrobia in soil bacterial communities. Soil Biol. Biochem. 43, 1450-1455. doi: 10.1016/j.soilbio.2011.03.012

Berthrong, S. T., Jobbágy, E. G., and Jackson, R. B. (2009). A global meta-analysis of soil exchangeable cations, $\mathrm{pH}$, carbon, and nitrogen with afforestation. Ecol. Appl. 198, 2228-2241. doi: 10.1890/08-1730.1

Cai, L., Ye, L., Tong, A. H. Y., Lok, S., and Zhang, T. (2013). Biased diversity metrics revealed by bacterial $16 \mathrm{~S}$ pyrotags derived from different primer sets. PLoS ONE 8:e53649. doi: 10.1371/journal.pone.0053649

Carbonetto, B., Rascovan, N., Álvarez, R., Mentaberry, A., and Vázquez, M. P. (2014). Structure, composition and metagenomic profile of soil microbiomes associated to agricultural land use and tillage systems in Argentine Pampas. PLoS ONE 9:e99949. doi: 10.1371/journal.pone.0099949

Cardoso, E. J. B. N., Vasconcellos, R. L. F., Bini, D., Miyauchi, M. Y. H., Santos, C. A. D., Alves, P. R. L., et al. (2013). Soil health: looking for suitable indicators. What should be considered to assess the effects of use and management on soil health? Sci. Agric. 70, 274-289. doi: 10.1590/S0103-90162013000400009

Chen, X., Cui, Z., Fan, M., Vitousek, P., Zhao, M., Ma, W., et al. (2014). Producing more grain with lower environmental costs. Nature 514, 486-489. doi: $10.1038 /$ nature 13609

Creswell, R., and Martin, F. W. (1998). Dry land Farming Crops and Techniques for Arid Regions. North Fort Myers, FL: ECHO.

Crowther, T. W., Maynard, D. S., Leff, J. W., Oldfield, E. E., McCulley, R. L., Fierer, N., et al. (2014). Predicting the responsiveness of soil biodiversity to deforestation: a cross-biome study. Glob. Change Biol. 20, 2983-2994. doi: $10.1111 / \mathrm{gcb} .12565$

Dai, A. (2013). Increasing drought under global warming in observations and models. Nat. Clim. Change 3, 52-58. doi: 10.1038/nclimate1811

\section{ACKNOWLEDGMENTS}

We acknowledge the use of data from NEON, which are made available subject to the NEON Data Policy (www.neoninc.org). This research is supported by Grains Research and Development Corporation (project UWS00008) and Australian Research Council (project DP13010484).

\section{SUPPLEMENTARY MATERIAL}

The Supplementary Material for this article can be found online at: http://journal.frontiersin.org/article/10.3389/fpls.2016.00990

Dalal, R. C., Thornton, C. M., and Cowie, B. A. (2013). Turnover of organic carbon and nitrogen in soil assessed from $\delta 13 \mathrm{C}$ and $\delta 15 \mathrm{~N}$ changes under pasture and cropping practices and estimates of greenhouse gas emissions. Sci. Total Environ. 465, 26-35. doi: 10.1016/j.scitotenv.2013.04.101

Del Galdo, L., Six, J., Peressotti, A., and Cotrufo, M. F. (2003). Assessing the impact of land-use change on soil $\mathrm{C}$ sequestration in agricultural soils by means of organic matter fraction and stable C isotopes. Glob. Change Biol. 9, 1204-1213. doi: 10.1046/j.1365-2486.2003.00657.x

Delgado-Baquerizo, M., Maestre, F. T., Gallardo, A., Bowker, M. A., Wallenstein, M. D., Quero, J. L., et al. (2013). Decoupling of soil nutrient cycles as a function of aridity in global drylands. Nature 502, 672-676. doi: 10.1038/nature12670

Delgado-Baquerizo, M., Maestre, F. T., Reich, P. B., Jeffries, T. C., Gaitan, J. J., Encinar, D., et al. (2016a). Microbial diversity drives multifunctionality in terrestrial ecosystems. Nat. Commun. 7:10541. doi: 10.1038/ncomms10541

Delgado-Baquerizo, M., Maestre, F. T., Reich, P. B., Trivedi, P., Osanai, Y., Liu, Y.-R., et al. (2016b). Carbon content and climate variability drive global soil bacterial diversity patterns. Ecol. Monogr. doi: 10.1002/ecm.1216 [Epub ahead of print].

Don, A., Schumacher, J., and Freibauer, A. (2011). Impact of tropical land-use change on soil organic carbon stocks- a meta-analysis. Glob. Change Biol. 17, 1658-1660. doi: 10.1111/j.1365-2486.2010.02336.x

Doran, J. W. (2002). Soil health and global sustainability: translating science into practice. Agric. Ecosyst. Environ. 88, 119-127. doi: 10.1016/S01678809(01)00246-8

Doran, J. W., and Zeiss, M. R. (2000). Soil health and sustainability: managing the biotic component of soil quality. Appl. Soil Ecol. 15, 3-11. doi: 10.1016/S09291393(00)00067-6

Engelbrektson, A., Kunin, V., Wrighton, K. C., Zvenigorodsky, N., Chen, F., Ochman, H., et al. (2010). Experimental factors affecting PCR-based estimates of microbial species richness and evenness. ISME J. 4, 642-647. doi: 10.1038/ismej.2009.153

Fargione, J., Hill, J., Tilman, D., Polasky, S., and Hawthorne, P. (2008). Land clearing and the biofuel carbon debt. Science 319, 1235-1238. doi: $10.1126 /$ science. 1152747

Feng, S., and Fu, Q. (2013). Expansion of global drylands under a warming climate. Atmos. Chem. Phys. 13, 081-100. doi: 10.5194/acp-13-10081-2013

Fierer, N., Bradford, M. A., and Jackson, R. B. (2007). Toward an ecological classification of soil bacteria. Ecology 88, 1354-1364. doi: 10.1890/051839

Fierer, N., Ladau, J., Clemente, J. C., Leff, J. W., Owens, S. M., Pollard, K. S., et al. (2013). Reconstructing the microbial diversity and function of preagricultural tallgrass prairie soils in the United States. Science 342, 621-624. doi: $10.1126 /$ science. 1243768

Fierer, N., Leff, J. W., Adams, B. J., Nielsen, U. N., Bates, S. T., Lauber, C. L., et al. (2012). Cross-biome metagenomic analyses of soil microbial communities and their functional attributes. Proc. Nat. Acad. Sci. U.S.A. 109, 21390-21395. doi: 10.1073/pnas. 1215210110

Fierer, N., Strickland, M. S., Liptzin, D., Bradford, M. A., and Cleveland, C. C. (2009). Global patterns in belowground communities. Ecol. Lett. 12, 1238-1249. doi: 10.1111/j.1461-0248.2009.01360.x 
Figuerola, E. L., Guerrero, L. D., Rosa, S. M., Simonetti, L., Duval, M. E., Galantini, J. A., et al. (2012). Bacterial indicator of agricultural management for soil under no-till crop production. PLOS ONE 7:e51075. doi: 10.1371/journal.pone.0051075

Figuerola, E. L., Guerrero, L. D., Türkowsky, D., Wall, L. G., and Erijman, L. (2015). Crop monoculture rather than agriculture reduces the spatial turnover of soil bacterial communities at a regional scale. Environ. Microbiol. 17, 678-688. doi: 10.1111/1462-2920.12497

Foley, J. A., DeFries, R., Asner, G. P., Barford, C., Bonan, G., Carpenter, S. R., et al. (2005). Global consequences of land use. Science 309, 570-574. doi: 10.1126/science. 1111772

Fredriksson, N. J., Hermansson, M., and Wilén, B. M. (2013). The choice of PCR primers has great impact on assessments of bacterial community diversity and dynamics in a wastewater treatment plant. PLOS ONE 8:e76431. doi: 10.1371/journal.pone.0076431

Gans, J., Wolinsky, M., and Dunbar, J. (2005). Computational improvements reveal great bacterial diversity and high metal toxicity in soil. Science 309, 1387-1390. doi: $10.1126 /$ science. 1112665

Gelfand, I., Sahajpal, R., Zhang, X., Izaurralde, R. C., Gross, K. L., and Robertson, G. P. (2013). Sustainable bioenergy production from marginal lands in the US Midwest. Nature 493, 514-517. doi: 10.1038/nature 11811

Griffin, T. S., He, Z., and Honeycutt, C. W. (2005). Manure composition affects net transformation of nitrogen from dairy manures. Plant Soil 273, 29-38. doi: 10.1007/s11104-004-6473-5

Grime, J. P. (1997). Biodiversity and ecosystem function: the debate continues. Science 277, 1260-1261. doi: 10.1126/science.277.5330.1260

Gugino, B. K., Idowu, O. J., Schindelbeck, R. R., van Es, H. M., Wolfe, D. W., Moebius, B. N., et al. (2009). Cornell Soil Health Assessment Training Manual, 2nd Edn. Geneva: Cornell University.

Guo, L. B., and Gifford, R. M. (2002). Soil carbon stocks and land use change: a meta analysis. Glob. Change Biol. 8, 345-360. doi: 10.1046/j.1354-1013.2002.00486.x

He, Y., Zhou, B. J., Deng, G. H., Jiang, X. T., Zhang, H., and Zhou, H. W. (2013). Comparison of microbial diversity determined with the same variable tag sequence extracted from two different PCR amplicons. BMC Microbiol. 13:208. doi: 10.1186/1471-2180-13-208

Holden, S. R., and Treseder, K. K. (2013). A meta-analysis of soil microbial biomass responses to forest disturbances. Front. Microbiol. 4:163. doi: 10.3389/fmicb.2013.00163

Jangid, K., Williams, M. A., Franzluebbers, A. J., Sanderlin, J. S., Reeves, J. H., Jenkins, M. B., et al. (2008). Relative impacts of land-use, management intensity and fertilization upon soil microbial community structure in agricultural systems. Soil Biol. Biochem. 40, 2843-2853. doi: 10.1016/j.soilbio.2008.07.030

Jesus, E. C., Marsh, T. L., Tiedje, J. M., and Moreira, F. M. S. (2009). Changes in land use alter the structure of bacterial communities in Western Amazon soils. ISME J. 3, 1004-1011. doi: 10.1038/ismej.2009.47

Jobbagy, E. G., and Jackson, R. B. (2004). The uplift of soil nutrients by plants: biogeochemical consequences across scales. Ecology 85, 2380-2389. doi: 10.1890/03-0245

Johnson, D. W., and Curtis, P. S. (2001). Effects of forest management on soil C and N storage: meta analysis. For. Ecol. Manag. 140, 227-238. doi: 10.1016/S03781127(00)00282-6

Kennedy, A. C., and Stubbs, T. L. (2006). Soil microbial communities as indicators of soil health. Ann. Arid Zone 45:287.

Kibblewhite, M. G., Jones, R. G. A., Montaranella, L., Baritz, R., Huber, S., Arrouays, D., et al. (eds). (2008). Environmental Assessment of Soil for Monitoring: Volume VI Soil Monitoring System for Europe. Luxembourg: Office for Official Publications of the European Communities, 72.

Kottek, M., Grieser, J., Beck, C., Rudolf, B., and Rubel, F. (2006). World map of the Köppen-Geiger climate classification updated. Meteorol. Z. 15, 259-263. doi: 10.1127/0941-2948/2006/0130

Krausmann, F., Erb, K.-H., Gingrich, S., Haberl, H., Bondeau, A., Gaube, V., et al. (2013). Global human appropriation of net primary production doubled in the 20th century. Proc. Natl. Acad. Sci. U.S.A. 110, 324-329. doi: $10.1073 /$ pnas. 1211349110

Kuramae, E. E., Yergeau, E., Wong, L. C., Pijl, A. S., Veen, J. A., and Kowalchuk, G. A. (2012). Soil characteristics more strongly influence soil bacterial communities than land-use type. FEMS Microbiol. Ecol. 79, 12-24. doi: 10.1111/j.1574-6941.2011.01192.x
Kuske, C. R., Yeager, C. M., Johnson, S., Ticknor, L. O., and Belnap, J. (2012). Response and resilience of soil biocrust bacterial communities to chronic physical disturbance in arid shrublands. ISME J. 6, 886-897. doi: 10.1038/ismej.2011.153

Lal, R. (2004). Soil carbon sequestration impacts on global climate change and food security. Science 304, 1623-1627. doi: 10.1126/science.1097396

Lee-Cruz, L., Edwards, D. P., Tripathi, B. M., and Adams, J. M. (2013). Impact of logging and forest conversion to oil palm plantations on soil bacterial communities in Borneo. Appl. Environ. Microbiol. 79, 7290-7297. doi: 10.1128/AEM.02541-13

Li, D., Niu, S., and Luo, Y. (2012). Global patterns of the dynamics of soil carbon and nitrogen stocks following afforestation: a meta-analysis. New Phytol. 195, 172-181. doi: 10.1111/j.1469-8137.2012.04150.x

Long, S. P., Zhu, X.-G., Naidu, S. L., and Ort, D. R. (2006). Can improvement in photosynthesis increase crop yields. Plant Cell Environ. 29, 315-330. doi: 10.1111/j.1365-3040.2005.01493.x

Lugtenberg, B., and Kamilova, F. (2009). Plant-growth-promoting rhizobacteria. Annu. Rev. Microbiol. 63, 541-556. doi: 10.1146/annurev.micro.62.081307.162918

Mayes, M., Marin-Spiotta, E., Szymanski, L., Erdoğan, M. A., Ozdoğan, M., and Clayton, M. (2014). Soil type mediates effects of land use on soil carbon and nitrogen in the Konya Basin, Turkey. Geoderma 232, 517-527. doi: 10.1016/j.geoderma.2014.06.002

McLauchlan, K. (2006). The nature and longevity of agricultural impacts on soil carbon and nutrients: a review. Ecosystems 9, 1364-1382. doi: 10.1007/s10021005-0135-1

Mendez-Millan, M., Nguyen Tu, T. T., Balesdent, J., Derenne, S., Derrien, D., Egasse, C., et al. (2014). Compound-specific $13 \mathrm{C}$ and $14 \mathrm{C}$ measurements improve the understanding of soil organic matter dynamics. Biogeochemistry 118, 205-223. doi: 10.1007/s10533-013-9920-7

Millennium Ecosystem Assessment [MEA]. (2005). Ecosystems and Human Wellbeing: Synthesis. Washington, DC: Island Press.

Mueller, L., Schindler, U., Mirschel, W., Shepherd, T. G., Ball, B. C., Helming, K., et al. (2010). Assessing the productivity function of soils. A review. Agron. Sustain. Dev. 30, 601-614. doi: 10.1051/agro/ 2009057

Murty, D., Kirschbaum, M. U. F., McMurtrie, R. E., and McGilvray, A. (2002). Does conversion of forest to agricultural land change soil carbon and nitrogen? A review of the literature. Glob. Change Biol. 8, 105-123. doi: 10.1046/j.13541013.2001.00459.x

Nielsen, M. N., Winding, A., and Binnerup, S. (2002). Microorganisms as Indicators of Soil Health. Denmark: National Environmental Research Institute.

Pankhurst, C. E., Doube, B. M., and Gupta, V. V. S. R. (1997). "Biological indicators of soil health: synthesis," in Biological Indicators of Soil Health, eds C. E. Pankhurst, B. M. Doube, and V. V. S. R. Gupta (Wallingford: CAB International), 419-435.

Post, W. M., and Kwon, K. C. (2000). Soil carbon sequestration and landuse change: processes and potential. Glob. Change Biol. 6, 317-327. doi: 10.1046/j.1365-2486.2000.00308.x

Reynolds, J. F., Stafford, S. D. M., Lambin, E. F., Turner, B. L., Mortimore, M., Batterbury, S. P. J., et al. (2007). Global desertification: building a science for dryland development. Science 316, 847-851. doi: 10.1126/science. 1131634

Richter, D. D., and Markewitz, D. (1995). How deep is soil? BioScience 45, 600-609. doi: $10.2307 / 1312764$

Rodrigues, J. L., Pellizari, V. H., Mueller, R., Baek, K., Jesus, E. D. C., Paula, F. S., et al. (2013). Conversion of the Amazon rainforest to agriculture results in biotic homogenization of soil bacterial communities. Proc. Natl. Acad. Sci. U.S.A. 110, 988-993. doi: 10.1073/pnas.1220608110

Running, S. W. (2012). A measurable planetary boundary for the biosphere. Science 337, 1458-1459. doi: 10.1126/science. 1227620

Sala, O. E., Chapin, F. S., Armesto, J. J., Berlow, E., Bloomfield, J., Dirzo, R., et al. (2000). Global biodiversity scenarios for the year 2100. Science 287, 1770-1774. doi: 10.1126/science.287.5459.1770

Schlesinger, W. M., and Bernhardt, E. S. (2013). Biogeochemstry. An analysis of global change, 3rd Edn. New York, NY: Academic Press.

Searchinger, T., Heimlich, R., Houghton, R. A., Dong, F., Elobeid, A., Fabiosa, J., et al. (2008). Use of US croplands for biofuels increases greenhouse gases 
through emissions from land-use change. Science 319, 1238-1240. doi: $10.1126 /$ science. 1151861

Serna-Chavez, H. M., Fierer, N., and Bodegom, P. M. (2013). Global drivers and patterns of microbial abundance in soil. Glob. Ecol. Biogeogr. 22, 1162-1172. doi: $10.1111 /$ geb. 12070

Sharma, S. K., Ramesh, A., Sharma, M. P., Joshi, O. P., Govaerts, B., Steenwerth, K. L., et al. (2011). "Microbial community structure and diversity as indicators for evaluating soil quality," in Biodiversity, Biofuels, Agroforestry and Conservation Agriculture, ed. E. Lichtfouse (Dordrecht: Springer), 317-358.

Singh, B. K., Quince, C., Macdonald, C. A., Khachane, A., Thomas, N., Abu AlSoud, W., et al. (2014). Loss of microbial diversity in soils is coincident with reductions in some specialized functions. Environ. Microbiol. 16, 2408-2420. doi: $10.1111 / 1462-2920.12353$

Smith, P., House, J. I., Bustamante, M., Sobocká, J., Harper, R., Pan, G., et al. (2015). Global change pressures on soils from land use and management. Glob. Change Biol. doi: 10.1111/gcb.13068 [Epub ahead of print].

Smith, W. K., Cleveland, C. C., Reed, S. C., and Running, S. W. (2014). Agricultural conversion without external water and nutrient inputs reduces terrestrial vegetation productivity. Geophys. Res. Lett. 41, 449-455. doi: 10.1002/2013GL058857

Strauss, G., and Fuchs, G. (1993). Enzymes of a novel autotrophic CO2 fixation pathway in the phototrophic bacterium Chloroflexus aurantiacus, the 3hydroxypropionate cycle. Eur. J. Biochem. 215, 633-643. doi: 10.1111/j.14321033.1993.tb18074.x

Tiessen, H., Stewart, J. W., and Bettany, J. R. (1982). Cultivation effects on the amounts and concentrations of carbon, nitrogen, and phosphorus in grassland soils. Agron. J. 74, 831-835. doi: 10.2134/agronj1982.00021962007400050015x

Tilman, D., Cassman, K. G., Matson, P. A., Naylor, R., and Polasky, S. (2002). Agricultural sustainability and intensive production practices. Nature 418, 671-677. doi: 10.1038/nature01014

Tilman, D., Fargione, J., Wolff, B., D’Antonio, C., Dobson, A., Howarth, R., et al. (2001). Forecasting agriculturally driven global environmental change. Science 292, 281-284. doi: 10.1126/science. 1057544

Trivedi, P., Anderson, I. C., and Singh, B. K. (2013). Microbial modulators of soil carbon storage: integrating genomic and metabolic knowledge for global prediction. Trends Microbiol. 21, 641-651. doi: 10.1016/j.tim.2013.09.005

Trivedi, P., Rochester, I. J., Trivedi, C., van Nostrand, J. D., Zhou, J., Karunaratne, S., et al. (2015). Soil aggregate size mediates the impacts of cropping regimes on soil carbon and microbial communities. Soil Biol. Biochem. 91, 169-181. doi: 10.1016/j.soilbio.2015.08.034

Upchurch, R., Chiu, C. Y., Everett, K., Dyszynski, G., Coleman, D. C., and Whitman, W. B. (2008). Differences in the composition and diversity of bacterial communities from agricultural and forest soils. Soil Biol. Biochem. 40, 1294-1305. doi: 10.1016/j.soilbio.2007.06.027

Vesterdal, L., Ritter, E., and Gundersen, P. (2002). Change in soil organic carbon following afforestation of former arable land. For. Ecol. Man. 169, 137-147. doi: 10.1016/S0378-1127(02)00304-3
Vitousek, P., Ehrlich, P., Ehrlich, A., and Matson, P. (1986). Human appropriation of the products of photosynthesis. BioScience 36, 368-373. doi: 10.2307/13 10258

Vitousek, P. M., Naylor, R., Crews, T., David, M. B., Drinkwater, L. E., Holland, E., et al. (2009). Nutrient imbalances in agricultural development. Science 324:1519. doi: 10.1126/science.1170261

Wall, D. H., Bardgett, R. D., and Kelly, E. F. (2010). Biodiversity in the dark. Nat. Geosci. 3, 297-298. doi: 10.1038/ngeo860

Wiesmeier, M., von Lützow, M., Spörlein, P., Geuß, U., Hangen, E., Reischl, A., et al. (2015). Land use effects on organic carbon storage in soils of Bavaria: the importance of soil types. Soil Tillage Res. 146, 296-302. doi: 10.1016/j.still.2014.10.003

Wu, H. B., Guo, Z. T., and Peng, C. H. (2003). Land use induced changes of organic carbon storage in soils of China. Glob. Change Biol. 9, 305-315. doi: 10.1046/j.1365-2486.2003.00590.x

Yang, Y., Luo, Y., and Finzi, A. C. (2011). Carbon and nitrogen dynamics during forest stand development: a global synthesis. New Phytol. 190, 977-989. doi: 10.1111/j.1469-8137.2011.03645.x

Yonekura, Y., Ohta, S., Kiyono, Y., Aksa, D., Morisada, K., Tanaka, N., et al. (2012). Dynamics of soil carbon following destruction of tropical rainforest and the subse-quent establishment of Imperata grassland in Indonesian Borneo using stable carbon isotopes. Glob. Change Biol. 18, 2606-2616. doi: 10.1111/j.13652486.2012.02722.x

Zhang, K., Cheng, X., Dang, H., Ye, C., Zhang, Y., and Zhang, Q. (2013). Linking litter production, quality and decomposition to vegetation succession following agricultural abandonment. Soil Biol. Biochem. 57, 803-813. doi: 10.1016/j.soilbio.2012.08.005

Zhang, K., Dang, H., Zhang, Q., and Cheng, X. (2015). Soil carbon dynamics following land-use change varied with temperature and precipitation gradients: evidence from stable isotopes. Glob. Change Biol. 21, 2762-2772. doi: $10.1111 /$ gcb. 12886

Zhu, L., and Southworth, J. (2013). Disentangling the relationships between net primary production and precipitation in southern Africa savannas using satellite observations from 1982 to 2010. Remote Sens. 5, 3803-3825. doi: $10.3390 /$ rs 5083803

Conflict of Interest Statement: The authors declare that the research was conducted in the absence of any commercial or financial relationships that could be construed as a potential conflict of interest.

Copyright (c) 2016 Trivedi, Delgado-Baquerizo, Anderson and Singh. This is an openaccess article distributed under the terms of the Creative Commons Attribution License (CC BY). The use, distribution or reproduction in other forums is permitted, provided the original author(s) or licensor are credited and that the original publication in this journal is cited, in accordance with accepted academic practice. No use, distribution or reproduction is permitted which does not comply with these terms. 